Bull. Fac .Agric., Cairo Univ. 64:140-151 (2013).

\title{
NITROGEN FERTILIZER USE EFFICIENCY IN SOME WHEAT CULTIVARS
}

(Received: 24.4.2013 )

\author{
By \\ H.S.A. Fateh and S. M . Abdel - Dayem* \\ Central Laboratory of Design \& Statistical Analysis Research and * Wheat Research Department, \\ Field Crops Research Institute, Agriculture Research Center, Giza, Egypt.
}

\begin{abstract}
Two field experiments were carried out at Zarzora Agricultural Research Station, Etay-El- Barod, ElBehera Governorate, Egypt during 2010/2011 and 2011/2012 seasons to study the effect of different nitrogen levels on some cultivars of wheat. The experiment layout was a split plot design with four replications. This experiment included 25 treatments. Five cultivars, i.e. Sakha 93, Sakha 94, Giza 168, Sids 12 and Misr 1, were randomly distributed in the main plots and five nitrogen levels $(0,30,60,90$ and $120 \mathrm{~kg}$ $\mathrm{N} /$ fed.) were randomly allocated in the sub- plots. The area of each sub - plot was $4.5 \mathrm{~m}^{2}$. This study was performed to find out the yielding ability of some local wheat cultivars as affected by nitrogen fertilization. The techniques utilized include fitting polynomial curves and performing economic analysis of the response curve.

The results indicated that all cultivars significantly differed in all the studied traits. Sids 12 was superior to the other cultivars in spike length, the number of grains/spike and 1000-grain weight in both seasons. Sids 12 and Giza 168 out - yielded Sakha 93 and Sakha 94, while Misr 1 was the poorest yielding of grains in both seasons. Nitrogen rates significantly influenced spike length. The tallest spikes were obtained at 90 and $120 \mathrm{~kg} \mathrm{~N} /$ fed and the shortest at the minimum nitrogen rate. Number of grains/spike and $1000-$ grain weight were significantly different at the extremes of nitrogen applications. The highest grain yield was obtained at $90 \mathrm{~kg} \mathrm{~N} /$ fed. in both seasons. It was concluded that the maximum grain yield could be obtained by sowing Sids 12 and Giza 168 wheat cultivars under $90 \mathrm{~kg} \mathrm{~N} /$ fed. The quadratic model was the best among the response models tested for describing response of grain yield of the five wheat cultivars to the nitrogen levels in both seasons.

The economic optimum $\mathrm{N}$ rate ranged from 71.83 to $85.21 \mathrm{~N} \mathrm{~kg} /$ fed. Grain yield at the optimum nitrogen rate ranged from 17.81 to $20.57 \mathrm{ard} /$ fed. Return ranged from 5548.31 to $6475.42 \mathrm{LE} / \mathrm{fed}$.
\end{abstract}

Key words: Economic Analysis and Return, Linear, nitrogen fertilizer, Polynomial Regression, Quadratic, quadratic and expontial, Square root, wheat cultivars.

\section{INTRODUCTION}

Increasing wheat productivity under Egyptian conditions is one of the main targets of wheat agronomists. Yield of wheat is a function of many factors among which the cultivars and nitrogen fertilization being the most important ones.

Several investigators reported that wheat cultivars significantly differed in grain yield and most of the studied characters. Hassanein et al. (1997) and El- Karamity (1998) found that Sids cultivars (Sids 6, 7 and 8) surpassed Giza 163, Giza 164 and Sakha 69 in yield components, grain and straw yields. Abdel Magied (1999) reported that
Sakha 69 and Giza 157 cultivars gave the highest grain yield/fed. Mohamed (1999) found that Sids 3, Giza 167 and Sids 1 had the highest spike yield. Also, Giza 167, Gemmiza 5 and Sids 3 gave heavier 1000- grain weight. However, Giza 164, Gemmiza 5 and Gemmiza 1 were loaded with the higher number of kernels / spike. Moreover, Sids 3, Sids 1 and Giza 167 secured higher grain yield. Although variety response significantly differed in most cases, no varietal $\mathrm{x}$ fertilizer interaction was recorded except spike yield and grain yield in the second season. Spike yield, 1000- grain weight and the number of grains / spike were the most 
prominent effects on grain yield variation with $\mathrm{R}^{2}$ value being 94\%. Salem (1999) indicated that Sids 6 gave the highest grain and protein yield, while Sids 4 gave the highest straw yield. While, Sharshar and El- Said (2000) reported that wheat cultivars significantly differed in grain yield and most of the measured traits. Moreover, the highest number of spikelets per spike and grain yield/ fed were recorded on Sakha 69 wheat cultivar. Ashmawy and Abo- Warda (2002) indicated that Giza 168 cultivar significantly surpassed Sids 1 and Gemmiza 9 cultivars in all the studied characters. The highest grain yield was obtained on Sakha 93 followed by Giza 168 in both seasons. Gemmiza 9 produced the lowest grain yield in both seasons. Abd-El-Nour and El-Fateh (2011) found that Shandaweel cultivar gave the lowest yield, while the other two genotypes Giza 168, and Dovin - 2 gave the highest grain yield in both seasons.

It has been found that nitrogen element is the most limiting factor for increasing wheat grain yield. Even though,the results of many research work in Egypt stressed that the optimum $\mathrm{N}$ fertilization level for wheat, widely varied in amounts ranged between 80 up to $160 \mathrm{~kg} \mathrm{~N} / \mathrm{fed}$. as reported by Eman (1985), El- Ghareib and ElMonoufi (1988), Fayed (1992) (El - Shami et al. (1995), Essa (1996), Mostafa et al. (1997), Sorour et al. 1998, Mohamed 1999 and Mosalem et al. 1999). They found that the number of spikes $/ \mathrm{m}^{2}$, the number of grains / spike and grain yield of wheat were maximized by increasing nitrogen level. Ashmawy and Abo-Warda (2002) found that the highest grain yield / fed (16.78 ard) was produced by adding $120 \mathrm{~kg} \mathrm{~N} /$ fed. Applying nitrogen fertilizer up to $50 \mathrm{~kg} \mathrm{~N} / \mathrm{fed}$. caused significant increases in wheat yield. This view was also reported by Zeidan et al. (2009) who found that the highest grain yield was recorded by $50 \mathrm{~kg} \mathrm{~N} / \mathrm{fed}$ followed by $75 \mathrm{~kg}$ N/fed. Abd-El- Nour and ElFateh (2011) indicated that the favorable effect of increasing nitrogen fertilizer levels on the dry matter might be due to the fact that nitrogen fertilizer is considered as one of the essential nutrients for wheat growth and subsequently the grain and straw yield. Also, Giovani et al.(2012) indicated that the higher performance of yield components was associated with higher nitrogen levels and showing that the positive effect of nitrogen fertilizer levels on grain yield was related to better performance of grain yield components.
Yields of the crop are regressed against applied nutrient levels. Using response curve leads to calculate economic optimum levels. Khalil et al .(1986) reported that curve linear polynomials, considering cost factors, recommended $100 \mathrm{~kg} \mathrm{~N} /$ fed for the Delta, $60 \mathrm{~kg} \mathrm{~N} /$ fed for middle Egypt and $80 \mathrm{~kg} \mathrm{~N} \mathrm{/} \mathrm{fed} \mathrm{for} \mathrm{Upper} \mathrm{Egypt.} \mathrm{Mohamed}$ (1999) found that quadratic model was the best model fitted to the grain yield of wheat for all the studied cultivars except Gemmiza 5. He also noticed that grain yield was gradually increased by increasing nitrogen fertilizer rate. Ashmawy and Abo-Warda (2002) indicated that quadratic model worked well for describing the response of grain yield /fed. to nitrogen fertilization for the three tested cultivars during the two seasons. This model had the highest coefficient of determination $\left(\mathrm{R}^{2}\right)$ and the lowest standard error (SE) showing significant compared with linear model. Optimum nitrogen rate ranged from 84.4 to $103.0 \mathrm{~kg} / \mathrm{fed}$. Grain yield at optimum $\mathrm{N}$ level was ranged from 11.85 ard / fed to 20.30 ard / fed and the return ranged from 1093.8 LE/ fed to 1975.4 LE/ fed. Response curve for $\mathrm{N}$ and $\mathrm{K}$ nutrients are mostly quadratic and square root quadratic, while that for $\mathrm{P}$ and other immobile nutrients is linear plateau.

The present study was performed to find out the yielding ability of some local wheat cultivars as affected by nitrogen fertilization. The techniques utilized include fitting polynomial curves and performing economic analysis of the response curve.

\section{MATERIALS AND METHODS}

The present study was carried out at Zarzora Agricultural Research Station, Etay - El- Barod, ElBehera Governorate during the two successive seasons 2010/ 2011 and 2011/ 2012. The experiment layout was a split plot design with four replications. This experiment included 25 treatments. Five cultivars i.e. Sakha 93, Sakha 94, Giza 168, Sids 12 and Misr 1, randomly distributed in the main plot, and five nitrogen levels (without $\mathrm{N}, 30,60,90$ and $120 \mathrm{~kg} \mathrm{~N} / \mathrm{fed}$.) were randomly allocated in the sub plots. The area of each sub plot was $4.5 \mathrm{~m}^{2}$ (1.5m wide and $3 \mathrm{~m}$ length). The preceding crop was cotton in both seasons. Wheat seeds were drilled in rows $20 \mathrm{~cm}$ apart at seeding rate of $60 \mathrm{~kg} / \mathrm{fed}$. Phosphate fertilizer at the rate of $15.5 \mathrm{~kg} \mathrm{P}_{2} \mathrm{O}_{5} / \mathrm{fed}(100 \mathrm{~kg}$ calcium super phosphate) was added during seed bed 
preparation.The amount of nitrogen as ammonium nitrate $(33.5 \mathrm{~N})$.was divided into two portions, one being applied immediately before the first irrigation and the rest was applied before the second irrigation. Soil structure and chemical analysis of the experimental field are presented in Table (1).

Table (1).Chemical and physical characteristic of the experimental field before experiment performance.

\begin{tabular}{|l|c|c|}
\hline Characteristics & $\begin{array}{c}2010 / 2011 \\
\text { season }\end{array}$ & $\begin{array}{c}2011 / 2012 \\
\text { season }\end{array}$ \\
\hline \multicolumn{3}{|c|}{ Chemical analysis } \\
\hline PH & 7.71 & 7.52 \\
\hline O.M.\% & 1.32 & 1.24 \\
\hline EC mm & 1.51 & 1.23 \\
\hline CaCO 3\% & 5.21 & 4.82 \\
\hline N ( ppm) & 30.23 & 26.41 \\
\hline P (ppm) & 11.1 & 9.5 \\
\hline K (ppm) & 352 & 340 \\
\hline \multicolumn{3}{|c|}{ Mechanical analysis } \\
\hline Sand\% & 57.28 & 61.22 \\
\hline Silt \% & 32.21 & 30.32 \\
\hline Clay \% & 10.72 & 8.78 \\
\hline Textural Class & $\begin{array}{c}\text { Sandy } \\
\text { Loam }\end{array}$ & Sandy \\
\end{tabular}

Characteristics of spike length number of grains / spike and 1000- grain weight were recorded from ten plants, randomly chosen from the four inner rows for each plot. Grain yield was estimated on whole sub plot basis.

A single analysis of variance was separately done for the data of each season analysis according to Snedecor and Cochran (1980). Treatment means were compared using the least significant difference test (L.S.D.) at 0.05 level of significance according to Steel and Torrie (1987).

\section{Response curve analysis}

Decisions concerning optimum rates of nitrogen fertilization directly or indirectly involve fitting some type of models to the data collected when several rates of nitrogen fertilizer are applied. Four response models were fitted to the data of grain yield / fed for the five tested cultivars during the first and second seasons according to Neter et al. .(1990). The tested models were linear, quadratic, square root quadratic and exponential model.
Functional forms

Linear

Quadratic

Square root quadratic

Exponential

$$
\begin{aligned}
& \text { Equation } \\
& \begin{array}{l}
Y=a+b x \\
Y=a+b x+c x^{2} \\
Y=a+b x+c x^{1 / 2} \\
Y=a b^{x}
\end{array}
\end{aligned}
$$

Where, Y represents yield, $\mathrm{x}$ is the nutrient applied, a represents as intercept, $b$ and $c$ are coefficients of the regression equation.

Coefficient of determination $\left(\mathrm{R}^{2}\right)$, standard error of estimate (SE) and significance of the model were the basis considered comparing among the above mentioned response models. The significant model that had the highest $\left(\mathrm{R}^{2}\right)$ value and the lowest estimate (SE) was the best model for describing the relationship between grain yield and $\mathrm{N}$ fertilization.

\subsection{Economic analysis}

The economic techniques used to determine the optimum fertilizer rate heavily depend on the model used to fit data. Economic optimum fertilizer rate also depends directly on the price of the fertilizer and selling price of the grains.

For a single variable model being fitted to the data from a single site- year, the optimal rate could be obtained by optimizing the total profit equation (Engelstad, 1985, and Dillon and Anderson, 1990). In this case, since we are fixing the levels of all other factors throughout all our experiment plots, then the total profit equation represents returns for those fixed factors. Calculus techniques are then used to maximize the total profit.

The total profit equation is:

$$
\pi=P_{y} f(x)-P_{x} \mathbf{x}
$$

Where: $\boldsymbol{\pi}$ is the amount of profit, $\boldsymbol{P}_{\boldsymbol{y}}$ is the price of the product, $\boldsymbol{P}_{\boldsymbol{x}}$ is the price of input (in this case nitrogen), $x$ is the level of input (in this case nitrogen) and $\mathrm{f}(\mathrm{x})$ is the production function.

By taking the first derivative of the above profit equation with respect to $\mathrm{x}$ and equating that to zero:

$$
\frac{\sigma \pi}{\sigma_{x}}=P_{y} \sigma \frac{f(x)}{\sigma x}-P_{x}=0
$$

Which can be written as:

$$
P_{y} \sigma f(x) \sigma_{x}=P_{x}
$$

This gives the first order condition on profit maximization which says that the marginal value of the product should equal the fertilizer price at the optimum. Solving this first order condition for the 
level of $x$ (the only unknown) gives the optimum nitrogen level. In other words, the farmer would continue increasing nitrogen until the returns from the last unit added is just equal to that unit's price.

The price of ammonium nitrate as a source of nitrogen used in the present study and the price of wheat grains considered for the economic analysis were those prevailing in Cairo, Egypt during 2010 / 2011 and 2011 / 2012 i.e. LE 4.18 / kg for ammonium nitrate and LE 272 / ard in 2010 / 2011 and LE 352 / ard in 2011 / 2012 for wheat grains.

\section{RESULTS AND DISCUSSION \\ 3.1. Yield and yield components \\ 3.1.1. Effect of cultivars}

All cultivars significantly differed in spike length with Sids 12 exhibiting the highest and Sakha 93 the lowest values in both seasons (Table 2). Giza 168 and Sids 12 did not significantly differed in the number of grains / spike but both produced significantly higher number than did others in the first season, but in the second season, Sids 12 was superior to the other cultivars in the number of grains / spike. All cultivars significantly differ in 1000 - grain weight in the two seasons with Sids 12 was the heaviest, Giza 168 was intermediate and Misr 1 was the lightest. The grain yield (ard / fed) of Sids 12 and Giza 168 did not significantly differ but both exceeded that of Misr 1. Sids 12 and Giza 168 outyielded Misr1 and Sakha 94 while Sakha 93 had the poorest yielded of grains in both seasons. The highest grain yield/ fed recorded by Sids 12 in both seasons. This could be attributed to the heaviest 1000 - grain weight and spike length. On the other hand, the main contributing factors for the highest grain yield in both seasons were heaviest 1000 - grain weight and the great number of grains / spike. These results are in harmony with those obtained by Hassanein et al.(1997), El-Karamity (1998), Mohamed (1999), Ashmawy and Abo-Warda (2002), and AbdelNour and El- Fateh (2011).

\subsubsection{Effect of nitrogen levels}

Nitrogen rates significantly influenced spike length. The tallest spikes were obtained at 60, 90 and $120 \mathrm{~kg} \mathrm{~N} / \mathrm{fed}$ and the shortest at the control (without nitrogen) (Table 3). Numbers of grains / spike and 1000- grain weight were significantly different at the extremes in nitrogen applications. This was true in both seasons. The highest grain yield was obtained at $90 \mathrm{~kg} \mathrm{~N} /$ fed. in both seasons.
This increment may be attributed to the greatest spike length,the number of grains / spike and heavier 1000 - grain weight. The lowest grain yield recorded in the control and $30 \mathrm{~kg} \mathrm{~N} /$ fed. in both seasons. This reduction may be attributed to the lowest spike length, the number of kernels / spike and lightest 1000 - grain weight. These results agree with those obtained by Eman (1985), ElGhareib and El- Monoufi (1988), Fayed (1992) and Giovani et al. (2012).

\subsubsection{Effect of interactions}

Data in Table (4) indicated that spike length, the number of grains / spike, 1000- grain weight and grain yield ard / fed were significantly affected by the interaction between cultivars and nitrogen levels in both seasons. The maximum grain yield was obtained by sowing Sids 12 and Giza 168 cultivars under $90 \mathrm{~kg} \mathrm{~N} / \mathrm{fed}$. in both seasons. This increase may be due to the direct effect of nitrogen in increasing meristimatic activity and accumulation of photosynthesis assimilates in the reproductive organs of wheat plants which led to the increase in spike length, the number of grain / spike and 1000 - grains weight. These findings are similar to those obtained by Ashmawy and AboWarda (2002).

\subsubsection{Analysis of $\mathrm{N}$ response curve}

Linear, quadratic, square root quadratic and exponential models were fitted to the data of grain yield / fed for the tested wheat cultivars in the first and second seasons, respectively. Three bases were considered to compare among the four models i.e. coefficient of determination $\left(\mathrm{R}^{2}\right)$, standard error of estimate (SE) and the significance of the model. The significant model which had the highest $\mathrm{R}^{2}$ and lowest SE was the best model fitted to the yield data.

Table (5) shows the coefficient of determination $\left(\mathrm{R}^{2}\right)$, the standard error of estimate (SE) and the calculated $\mathrm{F}$ value of the four models to study the response of wheat yield to $\mathrm{N}$ fertilizer levels in both seasons. The results indicate clearly that the highest value of the coefficient of determination $\left(\mathrm{R}^{2}\right)$ was in favor of the quadratic model for the five tested cultivars in the two seasons of the study. The values of the $\mathrm{R}^{2}$ of quadratic model were $94.3 \%$ and $85.4 \%$ for Giza 168 in the two seasons, respectively. Coefficients of determination values were $87.4 \%$ and $81.4 \%$ in the first and the second seasons, respectively, for Sakha 93. Coefficients of determination values were $98.3 \%$ and $97.2 \%$ 
Table (2). Means of grain yield and its components as affected by cultivars in both seasons.

\begin{tabular}{|c|c|c|c|c|c|c|}
\hline \multirow{2}{*}{ Characters } & \multicolumn{5}{|c|}{ Cultivars } & \multirow{2}{*}{$\begin{array}{l}\text { L.S.D } \\
(\mathbf{0 . 0 5})\end{array}$} \\
\hline & Giza 168 & Sakha 93 & Sids 12 & Sakha 94 & Misr 1 & \\
\hline \multicolumn{7}{|c|}{$2010 / 2011$ season } \\
\hline Spike length $(\mathrm{cm})$ & 13.43 & 12.18 & $\underline{14.16}$ & 12.59 & 12.33 & 0.865 \\
\hline Number of grain s / spike & 62.65 & 58.15 & $\underline{64.05}$ & 61.15 & 60.55 & 3.448 \\
\hline 1000- grain weight $(\mathrm{g})$ & 49.38 & 45.55 & $\underline{52.19}$ & 45.88 & 45.74 & 1.441 \\
\hline Grain yield (ard/fed) & 14.760 & 14.056 & $\underline{15.180}$ & 14.385 & 14.209 & 0.730 \\
\hline \multicolumn{7}{|c|}{ 2011/2012 season } \\
\hline Spike length $(\mathrm{cm})$ & 11.940 & 11.040 & $\underline{12.545}$ & 11.395 & 11.360 & 0.289 \\
\hline Number of grain s / spike & 55.650 & 49.65 & $\underline{69.40}$ & 52.000 & 46.80 & 5.313 \\
\hline 1000 grain weight $(\mathrm{g})$ & 49.740 & 41.860 & $\underline{52.225}$ & 43.220 & 43.035 & 1.415 \\
\hline Grain yield (ard/fed) & 15.615 & 14.502 & $\underline{15.951}$ & 15.437 & 14.663 & 0.920 \\
\hline
\end{tabular}

Table (3). Means of grain yield and its components as affected by nitrogen levels (N) in both seasons.

\begin{tabular}{|c|c|c|c|c|c|c|}
\hline \multirow{2}{*}{ Characters } & \multicolumn{5}{|c|}{ Nitrogen fertilizer levels (kg N/fed) } & \multirow{2}{*}{$\begin{array}{l}\text { L.S.D } \\
(\mathbf{0 . 0 5})\end{array}$} \\
\hline & $\mathbf{0}$ & 30 & 60 & 90 & 120 & \\
\hline \multicolumn{7}{|c|}{ 2010/2011 season } \\
\hline Spike length (cm) & 11.64 & 13.03 & $\underline{13.40}$ & 13.30 & 13.30 & 0.544 \\
\hline Number of grains / spike & 46.50 & 60.30 & 65.45 & $\underline{72.50}$ & 61.80 & 3.105 \\
\hline 1000- grain weight (g) & 39.72 & 45.99 & 50.07 & $\underline{51.53}$ & 51.42 & 1.280 \\
\hline Grain yield(ard/fed) & 9.276 & 13.050 & 16.569 & $\underline{17.647}$ & 16.048 & 0.385 \\
\hline \multicolumn{7}{|c|}{ 2011/2012 season } \\
\hline Spike length $(\mathrm{cm})$ & 10.240 & 11.840 & $\underline{12.185}$ & 12.025 & 11.990 & 0.217 \\
\hline Number of grains / spike & 46.400 & 56.100 & 56.350 & $\underline{\mathbf{5 8 . 1 0 0}}$ & 56.550 & 4.618 \\
\hline 1000- grain weight $(\mathrm{g})$ & 42.665 & 45.265 & 47.390 & $\underline{48.065}$ & 47.265 & 1.673 \\
\hline Grain yield(ard/fed) & 10.254 & 13.710 & 16.930 & $\underline{18.802}$ & 16.472 & 0.858 \\
\hline
\end{tabular}

in the first and second seasons, respectively, for Sids $12 . \mathrm{R}^{2}$ the value for Sakha 94 was $99.1 \%$ and $99.2 \%$ in the first and second seasons, respectively. $\mathrm{R}^{2}$ value for Misr1 was $98.3 \%$ and $99.2 \%$ in the first and second seasons, respectively. The square root quadratic model ranked second concerning $\mathrm{R}^{2}$ value followed by exponential and linear models, respectively, for the five tested cultivars in both seasons. Exponential model had the lowest value of SE followed by quadratic, square root quadratic and linear models, respectively. The result in Table (5) showed clearly that the four tested models were significant where they had significant $F$ values.

It could be concluded that quadratic model was the best of the response models tested for describing the response of grain yield of wheat cultivars to nitrogen fertilizer in both seasons, (Table 5 and Figs. 1 to 10).These results are similar to those obtained by Ashmawy (1994), Schlegel et al. (1996) and El - Douby et al. (2001) who reported 
Table (4): Means of grain yield and its components as affected by the interaction between cultivars (V) and nitrogen levels $(N)$ in both seasons.

\begin{tabular}{|c|c|c|c|c|c|c|c|c|}
\hline \multirow[t]{2}{*}{ Interaction } & \multicolumn{2}{|c|}{$\begin{array}{c}\text { Spike length } \\
(\mathrm{cm})\end{array}$} & \multicolumn{2}{|c|}{$\begin{array}{c}\text { Number of grains / } \\
\text { spike }\end{array}$} & \multicolumn{2}{|c|}{$\begin{array}{c}1000 \text { - grain weight } \\
(\mathrm{g})\end{array}$} & \multicolumn{2}{|c|}{ Grain yield $(\operatorname{ard} / \mathrm{fed})$} \\
\hline & 2010/11 & 2011/12 & 2010/11 & 2011/12 & 2010/11 & 2011/12 & 2010/11 & 2011/12 \\
\hline \multicolumn{9}{|l|}{ Giza 168} \\
\hline Without N & 12.00 & 10.60 & 43.75 & 44.00 & 42.25 & 39.23 & 9.73 & 10.66 \\
\hline $30 \mathrm{~kg} \mathrm{~N} / \mathrm{fed}$ & 13.88 & 11.83 & 60.00 & 49.75 & 47.60 & 41.70 & 15.07 & 12.54 \\
\hline $60 \mathrm{~kg} \mathrm{~N} / \mathrm{fed}$ & 13.25 & 12.60 & 66.50 & 53.25 & 51.85 & 45.23 & 16.54 & 18.94 \\
\hline $90 \mathrm{~kg} \mathrm{~N} / \mathrm{fed}$ & 14.00 & 11.90 & 80.25 & 61.50 & 53.16 & 46.13 & $\mathbf{1 7 . 3 4}$ & 19.47 \\
\hline $120 \mathrm{~kg} \mathrm{~N} / \mathrm{fed}$ & 14.00 & 12.78 & 62.75 & 51.50 & 52.01 & 42.90 & 15.12 & 16.46 \\
\hline \multicolumn{9}{|l|}{ Sakha 93} \\
\hline Without N & 9.75 & 10.10 & 46.00 & 41.75 & 36.38 & 39.28 & 9.10 & 10.69 \\
\hline $30 \mathrm{~kg} \mathrm{~N} / \mathrm{fed}$ & 13.00 & 11.35 & 54.75 & 44.00 & 43.38 & 39.70 & 11.48 & 13.01 \\
\hline $60 \mathrm{~kg} \mathrm{~N} / \mathrm{fed}$ & 13.00 & 11.48 & 62.25 & 51.75 & 49.04 & 43.00 & 16.38 & 15.26 \\
\hline $90 \mathrm{~kg} \mathrm{~N} / \mathrm{fed}$ & 12.50 & 11.08 & 66.75 & 61.50 & 49.21 & 44.55 & 17.36 & 18.65 \\
\hline $120 \mathrm{~kg} \mathrm{~N} / \mathrm{fed}$ & 12.63 & 11.20 & 61.00 & 49.25 & 49.76 & 42.78 & 15.96 & 14.90 \\
\hline \multicolumn{9}{|l|}{ Sids 12} \\
\hline Without $\mathrm{N}$ & 12.13 & 10.35 & 45.25 & 59.75 & 41.00 & 51.20 & 9.07 & 9.29 \\
\hline $30 \mathrm{~kg} \mathrm{~N} / \mathrm{fed}$ & 14.14 & 12.75 & 63.00 & 60.25 & 50.13 & 51.33 & 13.86 & 14.43 \\
\hline $60 \mathrm{~kg} \mathrm{~N} / \mathrm{fed}$ & 15.01 & 13.48 & 71.00 & 69.00 & 54.81 & 54.23 & 16.92 & 17.72 \\
\hline $90 \mathrm{~kg} \mathrm{~N} / \mathrm{fed}$ & 15.01 & 13.83 & 76.75 & 73.50 & 56.55 & 51.50 & 17.45 & 20.52 \\
\hline $120 \mathrm{~kg} \mathrm{~N} / \mathrm{fed}$ & 14.51 & 12.33 & 64.25 & 84.50 & 58.46 & 52.88 & 18.60 & 17.79 \\
\hline \multicolumn{9}{|l|}{ Sakha 94} \\
\hline Without N & 11.38 & 10.03 & 48.50 & 44.75 & 38.25 & 34.93 & 9.28 & 10.26 \\
\hline $30 \mathrm{~kg} \mathrm{~N} / \mathrm{fed}$ & 11.87 & 11.65 & 67.50 & 56.75 & 44.05 & 44.18 & 12.78 & 14.85 \\
\hline $60 \mathrm{~kg} \mathrm{~N} / \mathrm{fed}$ & 12.88 & 11.23 & 62.00 & 59.75 & 47.68 & 47.20 & 16.80 & 17.13 \\
\hline $90 \mathrm{~kg} \mathrm{~N} / \mathrm{fed}$ & 12.50 & 11.98 & 67.50 & 58.00 & 50.53 & 44.55 & 17.68 & 18.21 \\
\hline $120 \mathrm{~kg} \mathrm{~N} / \mathrm{fed}$ & 12.75 & 12.10 & 60.25 & 59.00 & 48.88 & 45.25 & 15.40 & 16.74 \\
\hline \multicolumn{9}{|l|}{ Misr 1} \\
\hline Without N & 13.88 & 10.13 & 49.00 & 41.75 & 40.74 & 48.00 & 9.21 & 10.36 \\
\hline $30 \mathrm{~kg} \mathrm{~N} / \mathrm{fed}$ & 12.25 & 11.63 & 56.25 & 42.75 & 44.84 & 48.80 & 12.07 & 13.72 \\
\hline $60 \mathrm{~kg} \mathrm{~N} / \mathrm{fed}$ & 12.88 & 12.15 & 65.50 & 51.00 & 46.95 & 52.28 & 16.21 & 15.61 \\
\hline $90 \mathrm{~kg} \mathrm{~N} / \mathrm{fed}$ & 12.50 & 11.35 & 71.25 & 47.50 & 48.19 & 49.35 & 18.41 & 17.16 \\
\hline $120 \mathrm{~kg} \mathrm{~N} / \mathrm{fed}$ & 12.63 & 11.55 & 60.75 & 51.00 & 47.99 & 50.28 & 15.16 & 16.47 \\
\hline L.S.D at $5 \%$ & 1.32 & 0.59 & 7.08 & 11.88 & 2.97 & 3.170 & 1.50 & 1.85 \\
\hline
\end{tabular}

that the relation between grain yield and $\mathrm{N}$ fertilizer followed the quadratic model. The results in Table (5) showed that the computed values of $\mathrm{R}^{2}$ indicate that, 94.3, 87.4, 98.3, 99.1 and $98.3 \%$, of the total variability in the mean yield of cultivars Giza 148, Sakha 93, Sids 12, Sakha 94 and Masr 1, respectively, in the first season were explained by the estimated quadratic regression equation. In the second season, second degree equation explained $85.4,81.4,97.2,99.2$ and $99.2 \%$ of the total variation of grain yield of the five tested cultivars.

The maximum nitrogen rate estimated by the quadratic equation was $84.18,75.96,88.85,84.88$ and $93.23 \mathrm{~kg}$ N/ fed. for Giza 168, Sakha 93, Sids 12,Sakha 94 and Misr 1, in the first season respectively. In the second season, the maximum rate was $85.08,87.36,90.23,85.38$ and $99.25 \mathrm{~kg} \mathrm{~N} /$ fed .for Giza 168, Sakha 93, Sids 12, Sakha 94 and Misr 1, respectively, (Table 6). The results showed that Giza 168 and Sids 12 out yielded other cultivars in the two seasons, at the maximum level of nitrogen fertilizer recording 19.92 and 20.60 and18.65 and19.44 ard / fed in the first and the second seasons, respectively. 
Table (5): Coefficient of determination $\left(\mathbf{R}^{2}\right)$, standard error of estimate (SE) and calculated $F$ value for linear and quadratic, square root quadratic and exponential models for grain yield of wheat cultivars in both seasons.

\begin{tabular}{|c|c|c|c|c|c|c|c|c|c|c|c|c|c|c|c|}
\hline \multirow[b]{2}{*}{ Models } & \multicolumn{3}{|c|}{ Giza 168} & \multicolumn{3}{|c|}{ Sakha 93} & \multicolumn{3}{|c|}{ Sids 12} & \multicolumn{3}{|c|}{ Sakha 94} & \multicolumn{3}{|c|}{ Misr 1} \\
\hline & $\mathbf{R}^{2} \%$ & SE & F(cal) & $\mathbf{R}^{2} \%$ & SE & $\mathbf{F}($ cal $)$ & $\mathbf{R}^{2} \%$ & SE & F(cal) & $\mathbf{R}^{2} \%$ & SE & F(cal) & $\mathbf{R}^{2} \%$ & SE & $\mathbf{F}($ cal $)$ \\
\hline $\begin{array}{l}\text { 2010/2011 } \\
\text { Linear } \\
\text { Quadratic } \\
\text { Square root } \\
\text { Exponential }\end{array}$ & $\begin{array}{l}61.1 \\
94.3 \\
80.2 \\
64.1\end{array}$ & $\begin{array}{l}3.34 \\
1.59 \\
2.91 \\
0.22\end{array}$ & $\begin{array}{l}4.66 \\
15.81 \\
4.02 \\
5.42\end{array}$ & $\begin{array}{l}38.2 \\
87.4 \\
70.3 \\
42.2\end{array}$ & $\begin{array}{l}3.42 \\
1.90 \\
2.91 \\
0.24\end{array}$ & $\begin{array}{l}1.88 \\
6.85 \\
2.36 \\
2.25\end{array}$ & $\begin{array}{l}71.2 \\
98.3 \\
92.2 \\
69.3\end{array}$ & $\begin{array}{l}2.97 \\
0.85 \\
1.85 \\
0.22\end{array}$ & $\begin{array}{l}5.33 \\
63.01 \\
12.26 \\
6.78\end{array}$ & $\begin{array}{l}65.2 \\
99.1 \\
94.2 \\
63.3\end{array}$ & $\begin{array}{l}2.54 \\
0.44 \\
0.89 \\
0.19\end{array}$ & $\begin{array}{l}5.78 \\
144.3 \\
34.21 \\
5.26\end{array}$ & $\begin{array}{l}77.2 \\
98.3 \\
97.1 \\
73.2\end{array}$ & $\begin{array}{l}1.91 \\
0.49 \\
0.65 \\
0.16\end{array}$ & $\begin{array}{l}10.29 \\
97.40 \\
56.27 \\
8.19\end{array}$ \\
\hline
\end{tabular}


$2010 / 2011$ seasons

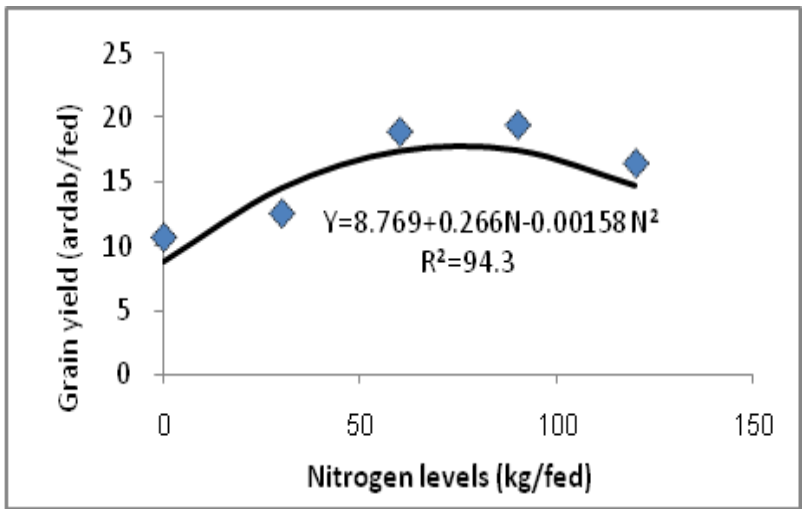

Fig. (1):Response of grain yield of wheat cultivar Giza 168 to $\mathbf{N}$ fertilizer

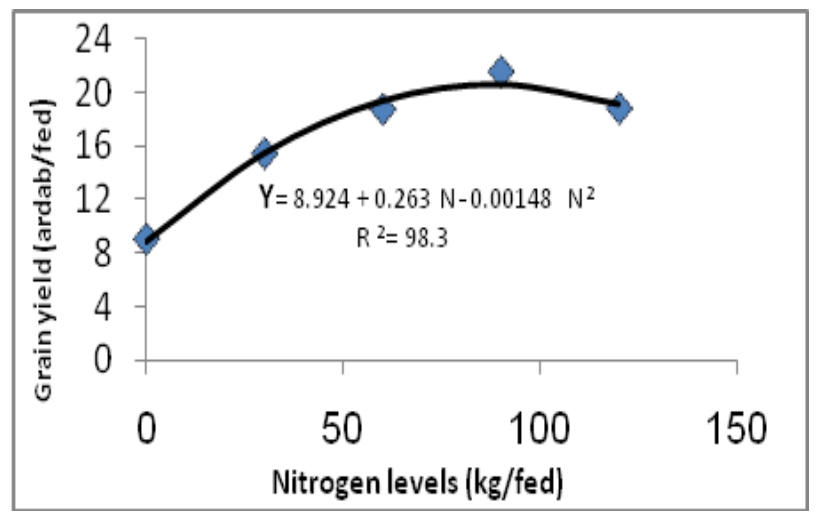

Fig. (3):Response of grain yield of wheat cultivar Sids 12 to $\mathbf{N}$ fertilizer

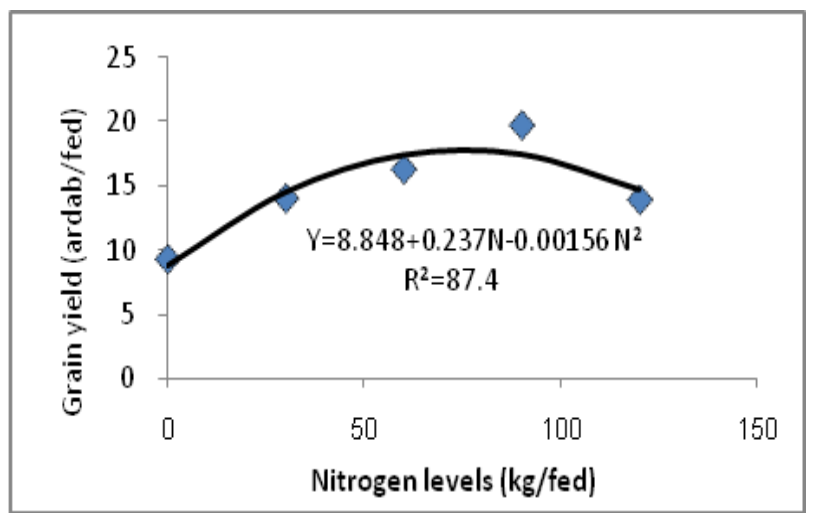

Fig.(2):Response of grain yield of wheat cultivar Sakha 93 to $\mathbf{N}$ fertilizer

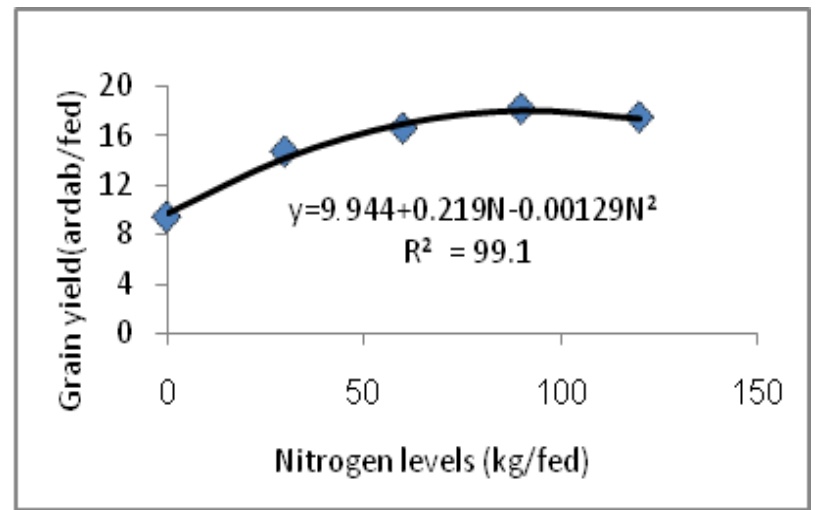

Fig. (4):Response of grain yield of wheat cultivar Sakha 94 to $\mathbf{N}$ fertilizer

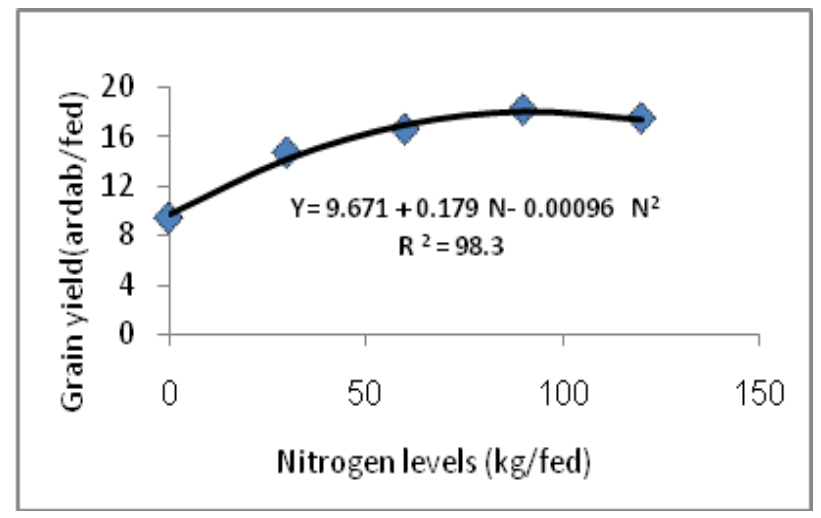

Fig.(5):Response of grain yield of wheat cultivar Misr 1 to $\mathbf{N}$ fertilizer 


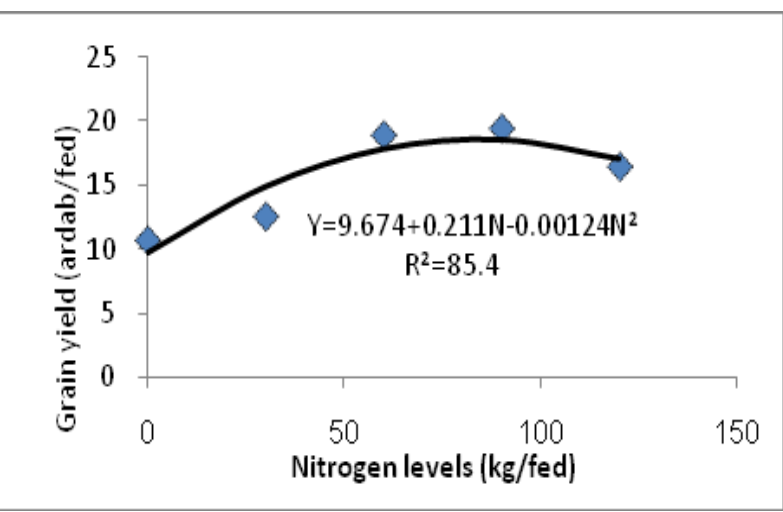

Fig.(6): Response of grain yield of wheat cultivar Giza 168 to $\mathbf{N}$ fertilizer

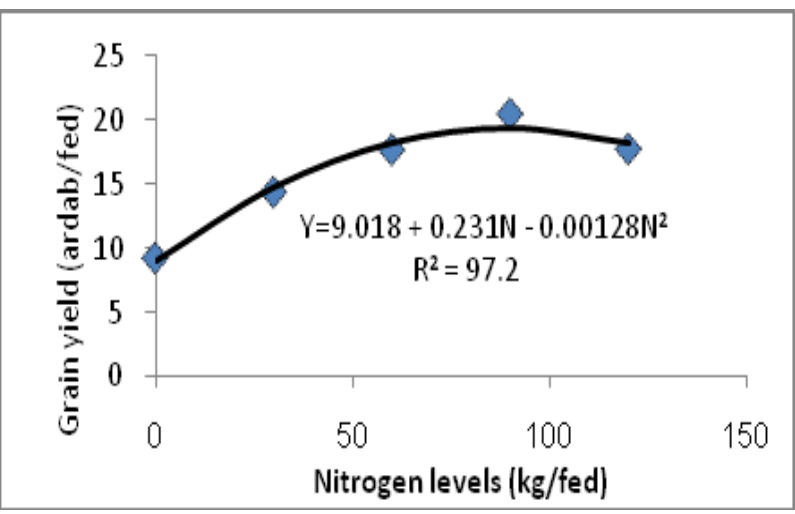

Fig.(8):Response of grain yield of wheat cultivar Sids 12 to $\mathrm{N}$ fertilizer

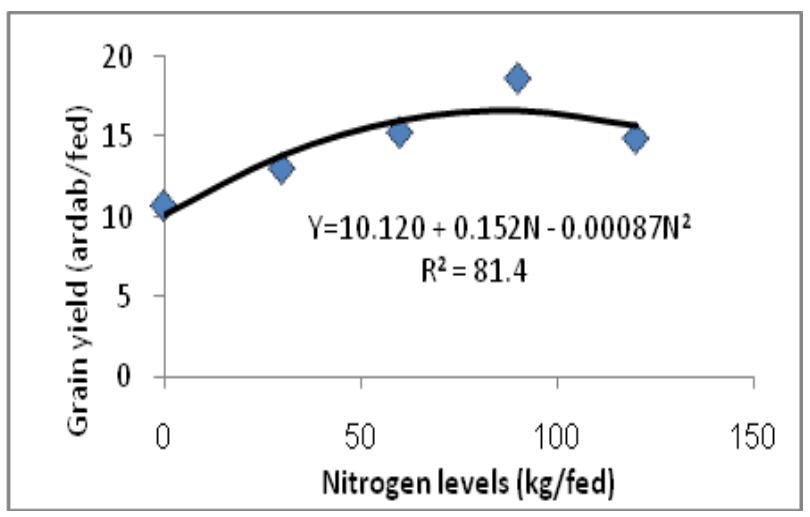

Fig.(7):Response of grain yield of wheat cultivar Sakha 93 to $\mathbf{N}$ fertilizer

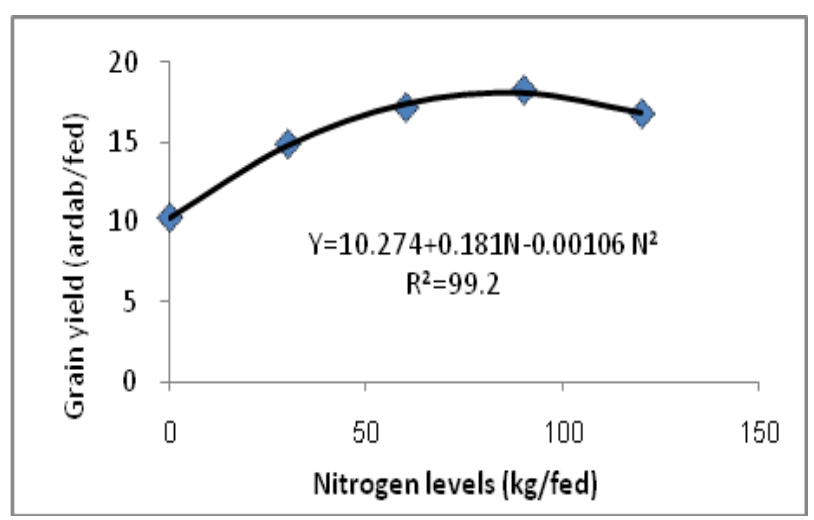

Fig.(9):Response of grain yield of wheat cultivar Sakha 94 to $\mathbf{N}$ fertilizer

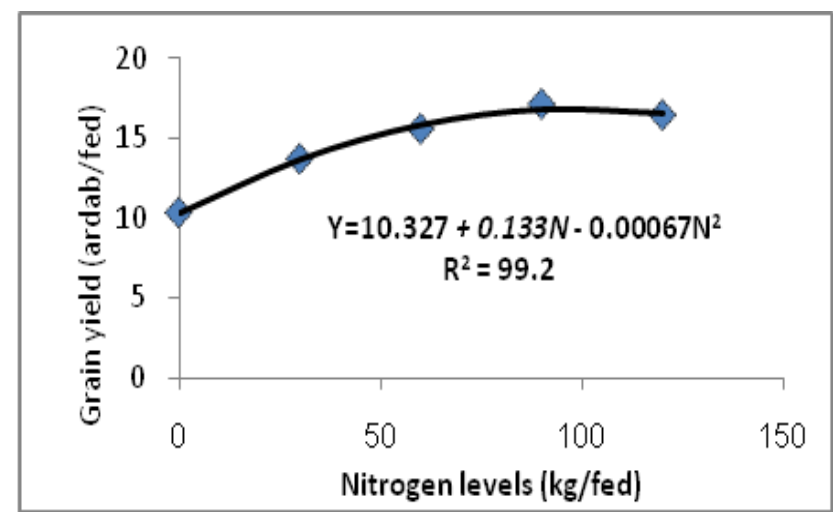

Fig.(10): Response of grain yield of wheat cultivar Misr 1 to $\mathbf{N}$ fertilizer 
Table (6): Regression (quadratic equations), maximum nitrogen level and grain yield at maximum nitrogen rates for wheat cultivars in both seasons .

\begin{tabular}{|c|c|c|c|c|c|c|}
\hline Cultivars & $\begin{array}{l}\text { Regression equations } \\
\text { ( quadratic model ) }\end{array}$ & $\begin{array}{c}\text { Maximum } \\
\text { N level } \\
\text { (kg/fed) }\end{array}$ & $\begin{array}{c}\text { Yield at } \\
\text { Maximum. } \\
\text { N levels } \\
\text { (ard/fed) } \\
\end{array}$ & $\begin{array}{c}\text { Econom } \\
\text { optimum. } \\
\text { N level } \\
\text { (kg/fed) }\end{array}$ & $\begin{array}{c}\text { Yield at } \\
\text { optimum. } \\
\text { N level } \\
\text { (ard/fed) }\end{array}$ & $\begin{array}{l}\text { Return } \\
(£ E / f e d)\end{array}$ \\
\hline \multicolumn{7}{|c|}{$\underline{2010 / 2011}$} \\
\hline Giza 168 & $Y=8.769+0.266 \mathrm{~N}-0.00158 \mathrm{~N}^{2}$ & 84.18 & 19.92 & 79.30 & 19.93 & 5088.67 \\
\hline Sakha 93 & $Y=8.848+0.237 N-0.00156 N^{2}$ & 75.96 & 17.85 & 71.03 & 17.81 & 4547.82 \\
\hline Sids 12 & $Y=8.924+0.263 N-0.00148 N^{2}$ & 88.85 & 20.60 & 83.65 & 20.57 & 5244.82 \\
\hline Sakha 94 & $Y=9.944+0.219 \mathrm{~N}-0.00129 \mathrm{N2}$ & 84.88 & 19.24 & 78.91 & 19.19 & 4890.58 \\
\hline Misr 1 & $Y=9.671+0.179 N-0.00096 N^{2}$ & 93.23 & 18.02 & 85.21 & $\mathbf{1 7 . 9 5}$ & 4527.11 \\
\hline \multicolumn{7}{|c|}{$\underline{2011 / 2012}$} \\
\hline Giza 168 & $Y=9.674+0.211 N-0.00124 N^{2}$ & 85.08 & 18.65 & 80.24 & 18.62 & 6219.17 \\
\hline Sakha 93 & $Y=10.120+0.152 \mathrm{~N}-0.00087 \mathrm{~N}^{2}$ & 87.36 & $\overline{16.76}$ & 80.46 & 16.72 & 5548.31 \\
\hline Sids 12 & $Y=9.018+0.231 N-0.00128 N^{2}$ & 90.23 & 19.44 & 85.55 & 19.41 & 6475.42 \\
\hline Sakha 94 & $Y=10.274+0.181 N-0.00106 N^{2}$ & 85.38 & $\overline{\mathbf{1 8 . 0 0}}$ & 79.72 & 17.97 & 5991.06 \\
\hline Misr 1 & $Y=10.327+0.133 N-0.00067 N^{2}$ & 99.25 & 16.93 & 90.30 & 16.87 & 5562.07 \\
\hline
\end{tabular}

\subsubsection{Economic analysis}

The results of the economic analysis of nitrogen fertilization are presented in Table (6). In the first season, the optimum nitrogen rate and grain yield at this rate ranged from 71.03 to $85.21 \mathrm{~kg} \mathrm{~N} /$ fed. and 17.81 to $20.57 \mathrm{ard} / \mathrm{fed}$, respectively. In the second season, the optimum nitrogen rate and grain yield at this rate ranged from 79.72 to $90.30 \mathrm{~kg} \mathrm{~N} /$ fed. and 16.72 to 19.41 ard / fed, respectively. The return ranged from 4527.11 to $5244.82 \mathrm{LE} / \mathrm{fed}$. in the first season. In the second season, optimum $\mathrm{N}$ rate ranged from 79.72 to $90.30 \mathrm{~kg} \mathrm{~N} /$ fed and the grain yield ranged from 16.72 to 19.41 ard / fed at the same $\mathrm{N}$ levels. Return ranged from 5548.31 to 6475.42 LE / fed. These results are in agreement with those reported by Mohamed (1999) and Ashmawy and Abo- Warda (2002).

The fact that the estimates of profitability and yield come from response functions to nitrogen fertilization is not quite sufficient to allow for accurate comparisons between the tested cultivars. For instance, information on the interaction between nitrogen and other variables is not considered when these optimals were calculated. Hence, these results should be interpreted cautiously. However, at least they give some indication about relative economic performance of the five tested wheat cultivars. A more detailed economic analysis would be required to verify these results.

\section{REFERENCES}

Abdel-Magied S.E.A. (1999). Effect of some agricultural practices on growth and yield of wheat. M. Sc. Thesis, Fac. Agric., Minia Univ., Egypt.

Abdel - Nour, Nadya A.R. and El-Fateh Hayam, S.A. (2011).Influence of sowing date and nitrogen fertilization on yield and its components in some bread wheat genotypes. Egypt, J. Agric. Res., 89(4): 1413-1433.

Ashmawy F. (1994). Multivariate and response curve analyses for important yield

factors in maize. Ph. D. Thesis, Fac. Agric., Moshtohor, Zagazig, Univ.

Ashmawy F.and Abo-Warda A.M.A. (2002). Response of some wheat cultivars to different seeding rates and nitrogen fertilization levels in sandy soil. Egypt,J. Appl.Sci., 17(10):136-157.

Dillon J.L. and Anderson J.R. (1990). The analysis of response in crop and livestock production. Pergman press. $3^{\text {rd }}$ Ed., New York. USA.

El-Douby K.A., Ali E.A,Toaima S.E.A. and.Abdel Aziz A.M (2001). Effect of nitrogen fertilizer, defoliation and plant density on maize grain yield. Egypt, J.Agric. Res., 79(3): 965-982.

El- Ghareib E.A. and El- Monoufi M.M. (1988). Effect of seeding rates and nitrogen fertilization levels on the productivity of Giza 157 Egyptian wheat cultivar. Ann. Agric.Sci., 
Fac. Agric.Ain.Shams Univ., 32(2): 10311044.

El- Karamity A.E. (1998). Response of some wheat cultivars to seeding and nitrogen fertilization rates. J.Agric. Sci., Mansoura Univ., 23(2): 643- 655

El- Shami M.M., Sharshar M. S. and Abd - El- Lahf A.H. (1995). Effect of late planting date and nitrogen fertilization on wheat. Egypt, J. Appl. Sci., 10(9):177-188.

Engelstad O.P. (1985). Fertilizer technology and use. Soil Science Society of America Inc. Madison, Wisconson, U.S.A.

Essa F. A. (1996). Agronomic studies on wheat. Ph.D.Thesis, Fac. Agric., El- Mansoura Univ., Egypt.

Fayed E.M.(1992).Effect of nitrogen, phosphorus and potassium fertilization on yield and yield attributes of wheat in newly cultivated sandy soil . Egypt.J. Appl. Sci., 7(12):886-898.

Giovani B., Elesandro B., Eduardo B. Eduardo S.P. Cristiano S.L. and Cilas P. (2012). Agronomic performance of wheat cultivars in response to nitrogen fertilization levels. Act. Scie. Agron. 34(3)1-7.

Hassanein M.S., Ahmed M.A. and.Hariri D.M (1997). Response of some wheat cultivars to different nitrogen sources.J.Agric.,Mansoura Univ. 22:349-360.

Khalil O.H.S., Mitkees R.A. ,Youssef G.S., ElHadidi M.M. and Mosaad M.G. (1986).Response of the newly released varieties of wheat to $\mathrm{N}, \mathrm{P}$, fertilizers. Assiut. J. Agric.Sci. 17(2):201:218.

Mosalem M.M.E., Zahran M. El- Menofi M. and Moussa M. M. E. (1999). Effect of sowing date, seeding rate and nitrogen level on wheat production. 2- Yield and yield components. Products Symp. of the Egyptian Society of plant Nutrition and Fertilization, September 1997, Cairo, pp. 83-96.

Mohamed N.A. (1999). Curve analysis for evaluation of the response of some wheat varieties to different nitrogen fertilization levels.J.Agric. Sci., Mansoura Univ., 24(4):1559 - 1571
Mostafa M.A., Helmy A.and Salem M.A. (1997). Effect of nitrogen fertilization on yield and yield components of wheat.(Triticum aestivum L.) under new land environment. J. Agric. Sci., Mansoura Univ., 22(1):1-11.

Neter J.,Wasserman W. and Kunter M.H. (1990).Applied Linear Statistical Models. $3^{\text {rd }}$ ed., IRWIN, Homewood, Boston, USA.

Sadek Eman M. (1985). Response of some wheat cultivars to different fertilizer rates M.Sc. Thesis, Fac. Agric. Cairo Univ., Egypt.

Salem M.A.M. (1999). Effect of sowing dates and seeding rates on productivity of three newly wheat caltivars (Triticum aestivum L).J. Agric. Sci.,Mansoura Univ., 24(9): 4379-4395.

Schlegel A.J., Dhuyvetter K.C. and Havlin J.L.(1996). Economic and environmental impacts of long - term nitrogen and phosphorus fertilization. J. Prod. Agric. 9(1):114-118.

Sharshar M.S. and El-Said S.A.(2000). Evalution of some wheat cultivars and lines under low and high inputs. J. Agric. Sc: Mansoura Univ., 25(6) 3109-3127

Snedecor G.W. and Cochran W.G. (1980). Statistical Methods, $7^{\text {th }}$ Ed., Iowa state Univ. Press, Ames, Iowa, U.S.A.

Sorour F.A., Mosalem M.E. and Khaffagy A. E. (1998). Effect of preceding crop, seeding rates and nitrogen levels on wheat growth, yield and its components. J. Agric. Res., Tanta Univ., 24(3): 263-281.

Steel R.G.D.and Torre J.H. (1987). Priniciples and procedures of statistics. A Biometrical Approach $2^{\text {nd }}, 6^{\text {th }}$ printing. Mc. Graw. Hill Book. Company.

Zeidan E.M., Abd - El- Hameed I.M. Bassiouny A.H. and Waly A.A. (2009). Effect of irrigation intervals, nitrogen and organic fertilization on yield, yield attribute and crude protein content of some wheat cultivars under newly reclaimed saline soil conditions. $4^{\text {th }}$ Conference on Recent Technologies in Agriculture,Fac. Agric., Cairo Univ., Egypt. 


\section{كفاءة إستخدام السماد الآزوتى فى بعض أصناف القمح \\ * هيام سيد أحمد فاتح - صبحى عحم عبد الدايم}

المعمل المركزى لبحوث التصميم و التحليل الأحصائى ـ * قسم بحوث القمح ـ معهد المحاصيل الحقلية

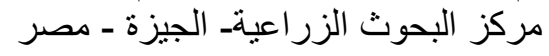

\footnotetext{
ملخصنص

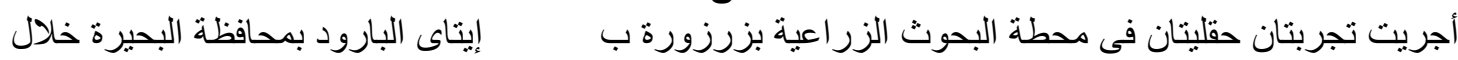

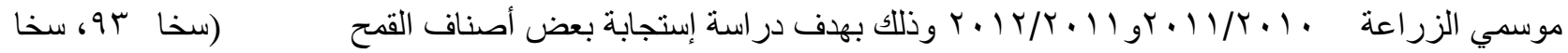

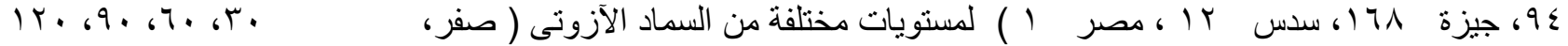

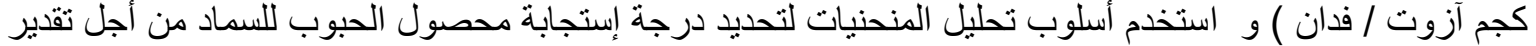

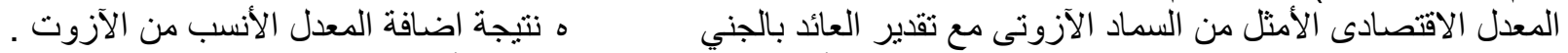

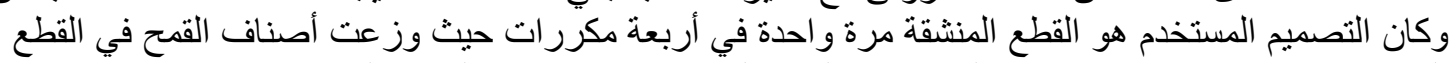

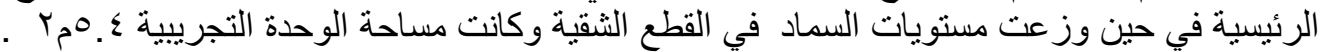
ويمكن تلخيص النتائج فيما يلى:

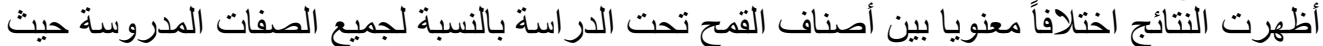

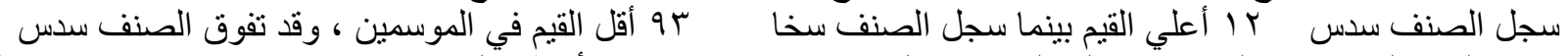

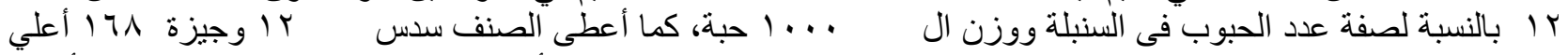

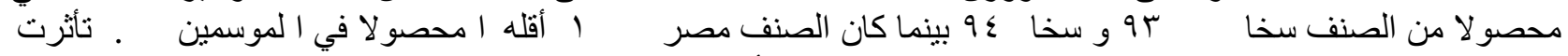

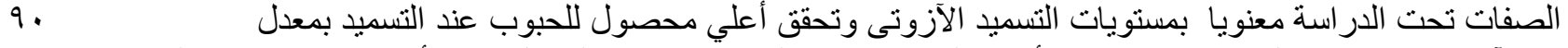
كجم آزوت / فدان في الموسمين،كما تأترت الصفات تحت الدر اسة معنويا بالتفاعل بين الأصناف ومستويات التسميد أظهرت النتائج المتحصل عليها أن العلاقة بين مستويات التسميد الآزوتى ومحصول الحبوب/

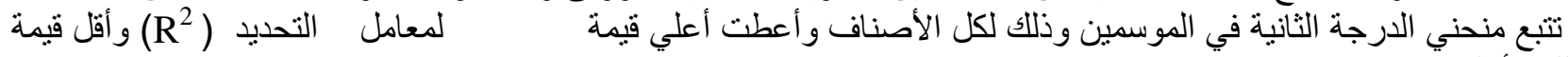

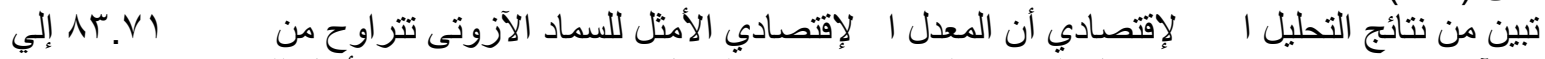

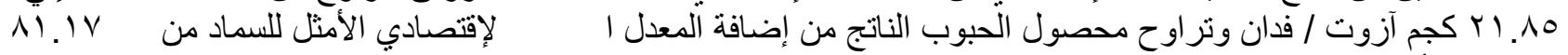

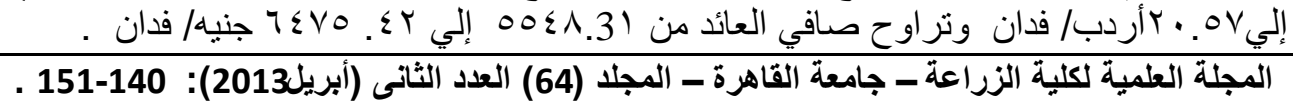

